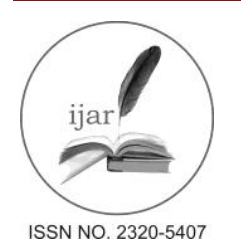

Journal homepage: http://www.journalijar.com

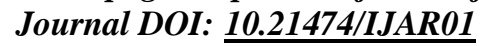

INTERNATIONAL JOURNAL

OF ADVANCED RESEARCH

RESEARCH ARTICLE

\title{
KNOWLEDGE, ATTITUDES AND PRACTICES RELATED TOPREGNANCYAMONG PREGNANT WOMEN IN SAMAR, PHILIPPINES.
}

Maricel M. Tizon, RN.

\section{Manuscript Info}

Manuscript History:

Received: 14 April 2016

Final Accepted: 19 May 2016

Published Online: June 2016

Key words:

knowledge, attitude, practices, pregnancy, Samar.

*Corresponding Author

Maricel M. Tizon, RN.

\begin{abstract}
Pregnancy is one of the most profound times in a woman's life. It is marked by variety of physical changes, as well as the thoughts and feelings that sometimes overwhelm the pregnant woman to be conscious about her pregnancy. Health knowledge, attitudes and practices are vital elements to enable the pregnant women to be aware of their health status and the importance of appropriate maternal self - care.This study assessed the knowledge, attitudes and practices related to pregnancy among pregnant women in Barangay San Andres, Catbalogan City, Province of Samar, Philippines. A descriptive-cross sectional method was adopted for this research and the data were collected over a period of two months from April 18 to August 17, 2013. One hundred pregnant women who were presented as the sample respondents were requested to complete the questionnaires regarding pregnancy. More than half $(63 \%)$ of the respondents $(n=63)$ scored within the score range of 12 to 15 which is interpreted as "Good Knowledge". In general, respondents have "positive attitude" and their typical practice related to pregnancy was interpreted as "poorly practiced" as supported by the grand means of 4.19 of 2.50 respectively. Vast majority of the pregnant women had very good knowledge (pregnant women were sufficiently knowledgeable with the concepts with regards to pregnancy), positive attitude $(\mathrm{m}=4.19)$, and poorpractice $(\mathrm{m}=2.5)$ in relation to pregnancy. The researchers would like to recommend that pregnant women should indulge in activities; campaign and other program and there should be a foregoing analysis that will help improve their knowledge, attitudes and practices and will enable them to provide appropriate health teachings on pregnancy related concepts.
\end{abstract}

Copy Right,IJAR, 2016...All rights reserved.

\section{Introduction:-}

Pregnancy is unique, exciting and often joyous tie in woman's life, as it highlights the woman's amazing creative and nurturing powers while providing a bridge to the future. However, complications of pregnancy can set in that can involve the mother's health, the baby's health, or both ${ }^{1}$.So, therefore, every woman needs to be aware of the key danger signs of obstetric complications during pregnancy, delivery and the postpartum period ${ }^{2}$. Pregnancy comes with some cost, however, for a pregnant woman needs also to be a responsible woman so as to best support the health of her future child ${ }^{3}$. According to the World Health Organization (WHO) and other collaborating agencies of 1987, they aimed to reduce the number of deaths associated with pregnancy and childbirth. It highlights the care of pregnant women as an important element in maternal healthcare that will lead to successful pregnancy outcome and healthy babies. ${ }^{4}$

Accelerated reduction in the incidence of maternal deaths alone can contribute substantially towards achieving Millennium Development Goals 5. ${ }^{5}$ Even though there is a positive trend of increase in knowledge of women about maternal and child care, and the pregnancy complications during the 1995 to 1999 period $^{6}$ still in 2013, about 3,000 
Filipino mothers died from childbirth out of 2.4 million deliveries and maternal mortality had settled at an unacceptably high level and was in a steady state $^{7}$.

Mothers' use of knowledge, resources, and supports provided a foundation for competent and confident mothering despite of other stressors in their lives. In the study of Passey et al. (2012) wherein, pregnant women had a generally good knowledge of risk but their knowledge of cessation was poor ${ }^{8}$.With regards to attitude of pregnant women related to pregnancy in 1896 Dabney described 90 cases of fetal abnormalities which he believed were associated with and caused by "maternal impressions" incurred in the course of pregnancy". And a similar conviction was also expressed by Ernest Jones, who emphasized that the mother's attitude towards the unborn child influences the course of pregnancy ${ }^{10}$. In the studies like of Muhamad et al., (2011), her study noted that pregnant women have positive attitude regarding prenatal care ${ }^{11}$ thus complications during pregnancy decreases. In the study ofRibeiro et al. 2011, almost two-thirds (65.6\%) of the women were sufficiently informed about the practice of physical exercise during pregnancy and the vast majority $(93.8 \%)$ was in favor of $\mathrm{it}^{12}$.

Indeed, health knowledge, attitudes and practices are vital elements to enable the pregnant women to be aware of their health status and the importance of appropriate maternal and child care. This study was conducted to determine the level of knowledge, attitudes and practices related to pregnancy among pregnant women in Brgy. San Andres, Catbalogan City that has been used as baseline data for further planning of health intervention program.

Therefore, there is a need to assess the knowledge, attitudes and practices related to pregnancy, because it will end with the birth of the baby and it is very much expected of the role being a pregnant woman both as a mother, and as a woman raising a child.

\section{Research Objective:-}

This study was conducted to determine the level of knowledge, attitudes and practices related to pregnancy among pregnant women in Brgy. San Andres, Catbalogan City, Samar, Philippines.

\section{Methodology:- \\ Design:-}

A descriptive- correlational method of research was utilized for this study. This design used to measure the relationship between pregnant women's profile and the different factors affecting their knowledge, attitudes and practices related to pregnancy.

\section{Samples and Settings:-}

Research data were collected using a questionnaireover the period of 3 months (April 18- August 17, 2013) from a convenience sample in one of the Barangays in Catbalogan, San Anders. One hundred pregnant women participated in the study. Pregnant were personally approached and asked if they were willing to participate in the study.

Instrumentation

The main source of data of the study was gathered through the use of a questionnaire. There were four sets of questionnaires: (a) demographic profile such as (b) knowledge related to pregnancy (c) attitude related to pregnancy (d) practices related to knowledge.

\section{Knowledge, Attitude and Practices Related to Pregnancy Questionnaire:- Knowledge Related to Pregnancy Questionnaire:-}

This instrument was developed by Muhamad et al. with modifications and this assesses the psychological result of perception, learning and reasoning of a particular woman towards pregnancy. The knowledge of the participant is being examined by various pregnancy related questions which are based on prenatal check-up and follow up, nutrition in pregnancy, screening test and preparation for delivery. It is consisted of twenty (20) statements. The respondents were given three alternatives indicating their reactions to each statement. The following point assignments were used: Uncertain (0), No (1), and Yes (2) response. 


\section{Attitude Related to Pregnancy Questionnaire:-}

This instrument was developed by Muhamad et al. with modifications and this expresses the feeling of a particular person related to pregnancy. The attitude of the participant is being examined by various pregnancy related questions which are based on prenatal check-up and follow up, nutrition in pregnancy, screening test and preparation for delivery. The attitude rating scale consisted of fourteen (14) statements. The respondents were given five alternatives indicating their reactions to each statement in the scale. The following point assignments to five different types of responses were used: Strongly Disagree (1), Disagree (2), Undecided (3), Agree (4), and Strongly Agree (5).

\section{Practices Related to Pregnancy:-}

The researchers established the questionnaire concerning the respondent's practices toward pregnancy. This determines the way of life of a particular pregnant woman towards pregnancy. The practices of the participant is being examined by various pregnancy related questions which are based on prenatal check-up and follow up, nutrition in pregnancy, screening test and preparation for delivery. The rating scale consisted of fifteen (15) statements. The respondents were given five alternatives indicating their reactions to each statement in the scale. The following point assignments were used: Never practice (1), Unsure (2), Sometimes Practice (3), Often Practice (4), and Always Practice (5).

\section{Data Collection Protocol:-}

Before the actual distribution of the questionnaire, a pilot study was undertaken to test the reliability and score distribution. The final distribution of the questionnaire was conducted after incorporating the modifications from the pilot study into the main study questionnaire. Letters of invitation with complete information about the study protocol were sent to the pregnant women in Barangay San Andres. After identifying potential study participants based on the eligible criteria, signed consent was obtained from the participants and data collection was carried out.

\section{Ethical Considerations:-}

The study protocol was reviewed and approved by the Health Ethics of Samar State University. Pregnant women rights were maintained through disclosure of the nature, benefits, and lack of known risk of the study. After the informed consent was signed, the researcher distributed the questionnaires at the respective site and collected them in sealed envelope upon completion. To maintain confidentiality and anonymity of the pregnant women, code numbers, instead of their names, were used in the questionnaires. Data were collected over a period of 3 months, from April 18 to August 17, 2013.

\section{Data Management and Analysis:-}

Data were analyzed using statistical Package for the Social Science (SPSS) version 16 (SPSS inc., Chicago, IL, USA) for descriptive and inferential statistics. Descriptive statistics such as frequencies, means, percentages, and standard deviations were utilized to qualify the responses of the respondents.

\section{Result:-}

Table 1

There were 100 respondents in the study. Majority of the respondents or $50(50 \%)$ were ages between 19 to 23 years old with mean age of 23.4 years and great number $(41 \%)$ of were married while 23 are single. Moreover, most of the respondents (37\%) were elementary level, in contrast only $1 \%$ had given the opportunity to graduate in college. And for the occupation, vast majority $(51 \%)$ were housewife and, more than of the respondents have family' monthly income between $100-1,000$ pesos per month. 


\begin{tabular}{|c|c|c|c|}
\hline Variable & & $\mathrm{N}$ & Percentage $(\%)$ \\
\hline \multirow[t]{6}{*}{ Age } & 14-18 & 13 & $13 \%$ \\
\hline & $19-23$ & 50 & $50 \%$ \\
\hline & $24-28$ & 21 & $21 \%$ \\
\hline & $29-33$ & 9 & $9 \%$ \\
\hline & 34- 38 & 6 & $6 \%$ \\
\hline & $39-43$ & 1 & $1 \%$ \\
\hline \multirow[t]{4}{*}{ Marital Status } & Single & 23 & $23 \%$ \\
\hline & Cohabitating/ Common Law & 36 & $36 \%$ \\
\hline & Married & 41 & $41 \%$ \\
\hline & Separated & 0 & $0 \%$ \\
\hline \multirow[t]{6}{*}{ Educational Attainment } & College graduate & 1 & $1 \%$ \\
\hline & College Level & 8 & $8 \%$ \\
\hline & High School Graduate & 9 & $9 \%$ \\
\hline & High School Level & 26 & $26 \%$ \\
\hline & Elementary Graduate & 19 & $19 \%$ \\
\hline & Elementary Level & 37 & $37 \%$ \\
\hline \multirow[t]{5}{*}{ Occupation } & Housewife & 51 & $51 \%$ \\
\hline & House servant (Maid) & 27 & $27 \%$ \\
\hline & Self- Employed & 22 & $22 \%$ \\
\hline & Student & 0 & $0 \%$ \\
\hline & Government Employee & 0 & $0 \%$ \\
\hline \multirow[t]{6}{*}{ Family's Monthly Income } & $100-1,000$ & 53 & $53 \%$ \\
\hline & $1,001-2,000$ & 15 & $15 \%$ \\
\hline & $2,001-3,000$ & 11 & $11 \%$ \\
\hline & $3,001-4,000$ & 3 & $3 \%$ \\
\hline & $4,001-5,000$ & 17 & $17 \%$ \\
\hline & 5,000 and above & 1 & $1 \%$ \\
\hline
\end{tabular}

In Table 2, majority of the respondents $(n=91)$ agreed that pregnant women need to go for prenatal check- up and $87 \%$ believe that prenatal class is good to prepare expecting mothers mentally. However, the statements, "pregnant woman sees the doctor for prenatal care only if she has pregnancy complication" and "diabetic women have higher risk of having big babies" attained the lowest percentages $14 \%$ and $24 \%$ respectively.

Table 3 presents the scores of the respondents on the questionnaires with regards topregnancy. More than half (63\%) of the respondents scored within the score range of 12 to 15 which is interpreted as "Good Knowledge", while $21 \%$ scored within the score range of 16 and above which is interpreted as "Very Good Knowledge". In general, mothers possess "Very Good Knowledge" being supported by the weighted mean of 20. 
Table 2 Knowledge related to Pregnancy among Pregnant

\begin{tabular}{|l|c|c|c|}
\hline \multicolumn{1}{|c|}{ Statements } & $\begin{array}{c}\text { Correct } \\
\text { answer }\end{array}$ & Frequency(f) & Percentage (\%) \\
\hline 1. Pregnant women need to go for prenatal check-up. & Yes & 91 & $91 \%$ \\
\hline $\begin{array}{l}\text { 2. First prenatal check-up should be done in the first } \\
\text { 3 months. }\end{array}$ & Yes & 77 & $77 \%$ \\
\hline 3. Pregnant woman needs vitamin supplement. & Yes & 77 & $77 \%$ \\
\hline 4. Maternal smoking is harmful to the fetus. & Yes & 81 & $81 \%$ \\
\hline $\begin{array}{l}\text { 5. Alcoholic drinks provide extra energy during } \\
\text { pregnancy. }\end{array}$ & No & 71 & $71 \%$ \\
\hline $\begin{array}{l}\text { 6. Pregnant woman needs to come for at least five } \\
\text { prenatal follow up throughout her pregnancy. }\end{array}$ & Yes & 40 & $40 \%$ \\
\hline $\begin{array}{l}\text { 7. Pregnant woman goes to the Healthcare Unit for } \\
\text { prenatal follow-up. }\end{array}$ & Yes & 85 & $85 \%$ \\
\hline $\begin{array}{l}\text { 8. Pregnant woman sees the doctor for pre-natal care } \\
\text { only if she has pregnancy complication. }\end{array}$ & No & 14 & $14 \%$ \\
\hline \multicolumn{1}{|c|}{ Does pregnant woman need to undergo the following test during her prenatal check-up? } \\
\hline 9. Blood screening for Hepatitis B infection. & Yes & 69 & $69 \%$ \\
\hline 10. Blood screening for HIV infection. & Yes & 68 & $68 \%$ \\
\hline 11. Blood screening for hemoglobin level. & Yes & 82 & $82 \%$ \\
\hline 12. Blood pressure examination. & Yes & 85 & $85 \%$ \\
\hline 13. Blood sugar level. & Yes & 64 & $64 \%$ \\
\hline 14, Urine tests for bacterial infection. & Yes & 65 & $38 \%$ \\
\hline 15. High blood pressure affects the fetus growth. & Yes & 38 & $24 \%$ \\
\hline $\begin{array}{l}\text { 16. Diabetic women have higher risk of having big } \\
\text { babies. }\end{array}$ & Yes & 24 & $69 \%$ \\
\hline 17. Ultrasound scan is safe for the fetus. & Yes & 69 & $76 \%$ \\
\hline $\begin{array}{l}\text { 18. Prenatal class is good to prepare expecting } \\
\text { mothers mentally. }\end{array}$ & Yes & 87 & $49 \%$ \\
\hline 19. Emotional disturbance affects fetal growth. & Yes & 49 & \\
\hline $\begin{array}{l}\text { 20. Women should deliver in the hospital for their } \\
\text { first pregnancy. }\end{array}$ & No & 76 & \\
\hline
\end{tabular}

Table 3 Level of Knowledge of Pregnant Women on Pregnancy

\begin{tabular}{|c|c|c|}
\hline Score Range & Frequency (n=100) & Percentage (\%) \\
\hline $16 \&$ Above & 21 & 21 \\
\hline $12-15$ & 63 & 63 \\
\hline $8-11$ & 11 & 11 \\
\hline $4-7$ & 3 & 3 \\
\hline $3 \&$ below & 2 & 2 \\
\hline Average Score & 20 & \\
\hline
\end{tabular}


Table 4 attitudes related to pregnancy

\begin{tabular}{|c|c|c|c|c|c|c|}
\hline Statements & $\begin{array}{c}\mathbf{1} \\
\text { SD } \\
\text { (n) } \%\end{array}$ & $\begin{array}{c}\mathbf{2} \\
\mathbf{D} \\
\text { (n)\% }\end{array}$ & $\begin{array}{c}\mathbf{3} \\
\mathbf{U} \\
\text { (n)\% }\end{array}$ & $\begin{array}{c}\mathbf{4} \\
\mathbf{A} \\
\text { (n) } \%\end{array}$ & $\begin{array}{c}\mathbf{5} \\
\text { SA } \\
\text { (n)\% }\end{array}$ & $\begin{array}{l}\text { Weighted } \\
\text { Mean }\end{array}$ \\
\hline $\begin{array}{l}\text { 1. Early prenatal check-up is good for my } \\
\text { pregnancy. }\end{array}$ & $(0) 0 \%$ & $(0) 0 \%$ & $(11) 11 \%$ & $\begin{array}{l}(54) \\
54 \%\end{array}$ & $(35) 35 \%$ & 4.24 \\
\hline $\begin{array}{l}\text { 2. I will go for prenatal check-up before } \\
\text { the third month of my pregnancy. }\end{array}$ & $(0) 0 \%$ & $(15) 15 \%$ & $\begin{array}{l}(10) \\
10 \%\end{array}$ & $\begin{array}{l}(56) \\
56 \%\end{array}$ & $\begin{array}{l}(19) \\
19 \%\end{array}$ & 3.79 \\
\hline $\begin{array}{l}\text { 3. I believe that vitamin supplement is } \\
\text { good for the fetus. }\end{array}$ & $(0) 0 \%$ & (0)0\% & $\begin{array}{l}(8) \\
8 \%\end{array}$ & $\begin{array}{l}(57) \\
57 \% \\
\end{array}$ & $\begin{array}{l}(35) \\
35 \%\end{array}$ & 4.68 \\
\hline $\begin{array}{l}\text { 4. I feel that smoking is harmful to the } \\
\text { fetus. }\end{array}$ & $(6) 6 \%$ & $(0) 0 \%$ & $\begin{array}{l}(2) \\
2 \%\end{array}$ & $\begin{array}{l}(36) \\
36 \%\end{array}$ & $\begin{array}{l}(56) \\
56 \%\end{array}$ & 4.36 \\
\hline $\begin{array}{l}\text { 5. I believe alcohol drinking will affect } \\
\text { fetal growth. }\end{array}$ & $(5) 5 \%$ & (12)12\% & $\begin{array}{l}(36) \\
36 \% \\
\end{array}$ & $\begin{array}{l}(22) \\
22 \% \\
\end{array}$ & $\begin{array}{l}(25) \\
25 \% \\
\end{array}$ & 3.5 \\
\hline $\begin{array}{l}\text { 6. I will go for prenatal check-up if I am } \\
\text { pregnant. }\end{array}$ & $(0) 0 \%$ & $(4) 4 \%$ & $\begin{array}{l}(15) \\
15 \%\end{array}$ & $\begin{array}{l}(58) \\
58 \%\end{array}$ & $\begin{array}{l}(23) \\
23 \%\end{array}$ & 4 \\
\hline $\begin{array}{l}\text { 7. Prenatal follow up is good to monitor } \\
\text { mother's and fetus' health. }\end{array}$ & $(0) 0 \%$ & $(0) 0 \%$ & $\begin{array}{l}(1) \\
1 \%\end{array}$ & $\begin{array}{l}(47) \\
47 \%\end{array}$ & $\begin{array}{l}(52) \\
52 \%\end{array}$ & 4.51 \\
\hline $\begin{array}{l}\text { 8. I will allow the doctor to take my blood } \\
\text { for screening. }\end{array}$ & $(0) 0 \%$ & $(0) 0 \%$ & $\begin{array}{l}(11) \\
11 \%\end{array}$ & $\begin{array}{l}(45) \\
45 \%\end{array}$ & $\begin{array}{l}(44) \\
44 \%\end{array}$ & 4.33 \\
\hline $\begin{array}{l}\text { 9. I will allow the doctor to check my } \\
\text { blood pressure. }\end{array}$ & $(0) 0 \%$ & $(0) 0 \%$ & $\begin{array}{l}(2) \\
2 \%\end{array}$ & $\begin{array}{l}(44) \\
44 \%\end{array}$ & $\begin{array}{l}(54) \\
54 \%\end{array}$ & 4.52 \\
\hline $\begin{array}{l}\text { 10. I will the doctor to check my blood } \\
\text { sugar level. }\end{array}$ & (3)3\% & (0)0\% & $\begin{array}{l}(26) \\
26 \% \\
\end{array}$ & $\begin{array}{l}(48) \\
48 \%\end{array}$ & $\begin{array}{l}(23) \\
23 \%\end{array}$ & 3.88 \\
\hline 11. I plan to deliver in the hospital. & $(0) 0 \%$ & $(5) 5 \%$ & (30) $30 \%$ & $\begin{array}{l}(35) \\
35 \%\end{array}$ & $\begin{array}{l}(30) \\
30 \%\end{array}$ & 3.91 \\
\hline $\begin{array}{l}\text { 12. I will do early preparation for the } \\
\text { delivery. }\end{array}$ & $(0) 0 \%$ & $(0) 0 \%$ & $\begin{array}{l}(1) \\
1 \%\end{array}$ & $\begin{array}{l}(51) \\
51 \%\end{array}$ & $\begin{array}{l}(48) \\
48 \%\end{array}$ & 4.47 \\
\hline $\begin{array}{l}\text { 13. I am ready to face any pregnancy and } \\
\text { delivery complication. }\end{array}$ & $(0) 0 \%$ & $(1) 1 \%$ & $\begin{array}{l}(18) \\
18 \%\end{array}$ & $\begin{array}{l}(50) \\
50 \%\end{array}$ & $\begin{array}{l}(31) \\
31 \%\end{array}$ & 4.11 \\
\hline $\begin{array}{l}\text { 14. I am willing to do ultrasound scan } \\
\text { during my pregnancy. }\end{array}$ & $(0) 0 \%$ & $(0) 0 \%$ & $\begin{array}{l}(12) \\
12 \% \\
\end{array}$ & $\begin{array}{l}(40) \\
40 \% \\
\end{array}$ & $\begin{array}{l}(48) \\
48 \% \\
\end{array}$ & 4.36 \\
\hline $\begin{array}{l}\text { Total } \\
\text { Grand Mean }\end{array}$ & & & & & & $\begin{array}{l}58.66 \\
4.19\end{array}$ \\
\hline
\end{tabular}

Table 4 presents the mean weighted ratings of the statements intended to measure the attitudes of pregnant womenrespondents related to pregnancy. Majority of the respondents $(n=58)$ agreed that they will go for prenatal check-up if pregnant, and more than half $(57 \%)$ believed that vitamin supplement is good for the fetus. However, $\mathrm{n}=6$ respondents felt that smoking is harmful to the fetus and 5\% believed that alcohol drinking will affect fetal growth. In general, a pregnant woman has "positive attitude" related to pregnancy as supported by the grand mean of 4. 19 . Table 5 presents the mean weighted ratings of the statements intended to determine the way of life of a particular pregnant woman towards pregnancy.Majority of the respondents $(\mathrm{n}=100,100 \%)$ never smokes during pregnancy,more than half $(\mathrm{n}=65)$ doesn't drink alcoholic beverages and $59 \%$ eat nutritious food like fruits and vegetables. Meanwhile, highest degree of practice of the respondents were noted, that $52 \%$ never gone to a doctor when sick (52\%, never), never intake of maternal milk (94\%), and 95\% never checked their blood sugar level one to three times a day. The typical practice of pregnant women related to pregnancy is interpreted as "poorly practiced" being supported by the grand mean of 2.5033 . 
Table 5 Practices Related to Pregnancy among Pregnant Women

\begin{tabular}{|c|c|c|c|c|c|c|}
\hline Statements & $\begin{array}{c}\mathbf{1} \\
\mathrm{N} \\
\text { (n) } \%\end{array}$ & $\begin{array}{c}2 \\
\mathbf{U} \\
\text { (n) } \%\end{array}$ & $\begin{array}{l}\mathbf{3} \\
\mathbf{S} \\
\text { (n) } \%\end{array}$ & $\begin{array}{c}4 \\
\mathbf{O} \\
\text { (n) } \%\end{array}$ & $\begin{array}{c}\mathbf{5} \\
\mathbf{A} \\
(\mathbf{n}) \%\end{array}$ & $\begin{array}{l}\text { Weighted } \\
\text { Mean }\end{array}$ \\
\hline $\begin{array}{l}\text { 1.I have a regular prenatal check- } \\
\text { up. }\end{array}$ & $\begin{array}{l}13 \% \\
(13)\end{array}$ & $\begin{array}{l}2 \% \\
(2)\end{array}$ & $\begin{array}{l}16 \% \\
(16)\end{array}$ & $\begin{array}{l}27 \% \\
(27)\end{array}$ & $\begin{array}{l}42 \% \\
(42)\end{array}$ & 3.83 \\
\hline $\begin{array}{l}\text { 2.I take prescribed vitamins and } \\
\text { supplements. }\end{array}$ & $\begin{array}{l}18 \% \\
(18)\end{array}$ & $\begin{array}{l}3 \% \\
(3)\end{array}$ & $\begin{array}{l}15 \% \\
(15)\end{array}$ & $\begin{array}{l}25 \% \\
(25)\end{array}$ & $\begin{array}{l}39 \% \\
(39)\end{array}$ & 3.64 \\
\hline $\begin{array}{l}\text { 3.I get enough sleep and try to } \\
\text { reduce stress. }\end{array}$ & $\begin{array}{l}2 \% \\
(2)\end{array}$ & $\begin{array}{l}0 \% \\
(0)\end{array}$ & $\begin{array}{l}33 \% \\
(33)\end{array}$ & $\begin{array}{l}39 \% \\
(39)\end{array}$ & $\begin{array}{l}26 \% \\
(26)\end{array}$ & 3.87 \\
\hline $\begin{array}{l}\text { 4.I do some stretching and exercise } \\
\text { for at least } 30 \text { minutes. }\end{array}$ & $\begin{array}{l}10 \% \\
(10)\end{array}$ & $\begin{array}{l}0 \% \\
(0) \\
\end{array}$ & $\begin{array}{l}23 \% \\
(23) \\
\end{array}$ & $\begin{array}{l}31 \% \\
(31) \\
\end{array}$ & $\begin{array}{l}36 \% \\
(36) \\
\end{array}$ & 3.83 \\
\hline 5.I smoke. & $\begin{array}{l}100 \% \\
(100)\end{array}$ & $\begin{array}{l}0 \% \\
(0)\end{array}$ & $\begin{array}{l}0 \% \\
(0)\end{array}$ & $\begin{array}{l}0 \% \\
(0)\end{array}$ & $\begin{array}{l}0 \% \\
(0)\end{array}$ & 1 \\
\hline 6.I drink alcoholic beverages. & $\begin{array}{l}65 \% \\
(65) \\
\end{array}$ & $\begin{array}{l}4 \% \\
(4)\end{array}$ & $\begin{array}{l}1 \% \\
(19) \\
\end{array}$ & $\begin{array}{l}11 \% \\
(11) \\
\end{array}$ & $\begin{array}{l}1 \% \\
(1)\end{array}$ & 1.79 \\
\hline $\begin{array}{l}\text { 7.I take over the counter drugs } \\
\text { when I have fever. }\end{array}$ & $\begin{array}{l}82 \% \\
(82)\end{array}$ & $\begin{array}{l}1 \% \\
(1)\end{array}$ & $\begin{array}{l}12 \% \\
(12)\end{array}$ & $\begin{array}{l}2 \% \\
(2)\end{array}$ & $\begin{array}{l}3 \% \\
(3)\end{array}$ & 1.43 \\
\hline $\begin{array}{l}\text { 8.I eat nutritious food (e.g. fruits, } \\
\text { vegetables). }\end{array}$ & $\begin{array}{l}3 \% \\
(3)\end{array}$ & $\begin{array}{l}1 \% \\
(1)\end{array}$ & $\begin{array}{l}17 \% \\
(17) \\
\end{array}$ & $\begin{array}{l}20 \% \\
(20) \\
\end{array}$ & $\begin{array}{l}59 \% \\
(59) \\
\end{array}$ & 4.31 \\
\hline 9.I go to a doctor when I'm sick. & $\begin{array}{l}52 \% \\
(52)\end{array}$ & $\begin{array}{l}2 \% \\
(2)\end{array}$ & $\begin{array}{l}18 \% \\
(18)\end{array}$ & $\begin{array}{l}7 \% \\
(7)\end{array}$ & $\begin{array}{l}21 \% \\
(21)\end{array}$ & 2.43 \\
\hline $\begin{array}{l}\text { 10.I drink caffeinated drinks such as } \\
\text { coffee. }\end{array}$ & $\begin{array}{l}24 \% \\
(24)\end{array}$ & $\begin{array}{l}7 \% \\
(7)\end{array}$ & $\begin{array}{l}43 \% \\
(43)\end{array}$ & $\begin{array}{l}17 \% \\
(17)\end{array}$ & $\begin{array}{l}5 \% \\
(5)\end{array}$ & 2.8 \\
\hline $\begin{array}{l}11 . I \text { check my blood pressure } \\
\text { weekly. }\end{array}$ & $\begin{array}{l}33 \% \\
(33)\end{array}$ & $\begin{array}{l}6 \% \\
(6)\end{array}$ & $\begin{array}{l}36 \% \\
(36)\end{array}$ & $\begin{array}{l}8 \% \\
(8)\end{array}$ & $\begin{array}{l}17 \% \\
(17)\end{array}$ & 2.7 \\
\hline $\begin{array}{l}\text { 12.I check my blood sugar level one } \\
\text { to three times a day. }\end{array}$ & $\begin{array}{l}95 \% \\
(95)\end{array}$ & $\begin{array}{l}0 \% \\
(0)\end{array}$ & $\begin{array}{l}5 \% \\
(5)\end{array}$ & $\begin{array}{l}0 \% \\
(0)\end{array}$ & $\begin{array}{l}0 \% \\
(0)\end{array}$ & 1.1 \\
\hline 13.I drink maternal milk. & $\begin{array}{l}94 \% \\
(94)\end{array}$ & $\begin{array}{l}0 \% \\
(0)\end{array}$ & $\begin{array}{l}0 \% \\
(0)\end{array}$ & $\begin{array}{l}0 \% \\
(0)\end{array}$ & $\begin{array}{l}6 \% \\
(6)\end{array}$ & 1.24 \\
\hline $\begin{array}{l}\text { 14.I do long standing activities } \\
\text { household } \\
\text { chore). }\end{array}$ & $\begin{array}{l}75 \% \\
(75)\end{array}$ & $\begin{array}{l}0 \% \\
(0)\end{array}$ & $\begin{array}{l}12 \% \\
(12)\end{array}$ & $\begin{array}{l}4 \% \\
(4)\end{array}$ & $\begin{array}{l}9 \% \\
(9)\end{array}$ & 1.72 \\
\hline $\begin{array}{l}\text { 15.I lift my legs as much as possible } \\
\text { after long standing. }\end{array}$ & $\begin{array}{l}57 \% \\
(57)\end{array}$ & $\begin{array}{l}9 \% \\
(9)\end{array}$ & $\begin{array}{l}27 \% \\
(27)\end{array}$ & $\begin{array}{l}3 \% \\
\text { (3) }\end{array}$ & $\begin{array}{l}3 \% \\
\text { (3) }\end{array}$ & 1.86 \\
\hline \multicolumn{6}{|l|}{ Total } & 37.55 \\
\hline \multicolumn{6}{|l|}{ Grand Mean } & 2.5 \\
\hline
\end{tabular}

Table 6 Correlation between Knowledge, Attitude and Practices and Profile of Pregnant Women-Respondents

\begin{tabular}{|l|l|l|l|c|c|c|}
\hline \multirow{2}{*}{ Variables } & \multicolumn{2}{c|}{ Knowledge } & \multicolumn{2}{c|}{ Attitudes } & \multicolumn{2}{c|}{ Practices } \\
\cline { 2 - 7 } & \multicolumn{1}{c|}{$\boldsymbol{r}_{\boldsymbol{x y}}$} & $\begin{array}{c}\text { p- } \\
\text { Value }\end{array}$ & $\boldsymbol{r}_{\boldsymbol{x y}}$ & p- Value & $\boldsymbol{r}_{\boldsymbol{x y}}$ & p- Value \\
\hline Age & 0.186 & 0.062 & -0.022 & 0.829 & 0.106 & 0.293 \\
\hline Marital Status & 0.091 & 0.365 & -0.056 & 0.579 & -0.04 & 0.684 \\
\hline Educational Attainment & 0.070 & 0.487 & -0.022 & 0.829 & 0.029 & 0.776 \\
\hline Occupation & -0.046 & 0.646 & 0.141 & 0.158 & 0.141 & 0.158 \\
\hline Family's Monthly Income & -0.108 & 0.281 & -0.131 & 0.191 & -0.121 & 0.227 \\
\hline *Correlation is significant at the level of 0.05 &
\end{tabular}

Table 6 shows the correlation analysis between respondents' knowledge on pregnancy and selected variables. The rvalue between knowledge on pregnancy and age $(\mathrm{p}=0.062)$, marital status $(\mathrm{p}=0.365)$, educational attainment (0.487), occupation $(\mathrm{p}=0.646)$ and family's monthly income $(\mathrm{p}=0.281)$. For the correlation analysis between respondents' attitudes on pregnancy and their selected profile reveals that age $(\mathrm{p}=0.829)$, marital status $(\mathrm{p}=0.579)$, educational attainment $(\mathrm{p}=0.829)$, occupation $(0.158)$ and family's monthly income $(\mathrm{p}=0.191)$. However for the 
correlation analysis between respondents' practices on pregnancy and their profile shows age $(p=0.293)$, marital status $(p=0.684)$, educational attainment $(p=0.776)$, occupation $(p=0.158)$ and family's monthly income $(0.227)$.

\section{Discussions:-}

Pregnancy is a unique and one of the most precious moments for women, however complications can occur during pregnancy. They can involve the mother's health, the baby's health, or both ${ }^{13}$.Hence, along with the Millennium Development Goal (MDG) 5 which is to improve maternal health ${ }^{14}$, every woman needs to be aware of the key danger signs of obstetric complications during pregnancy, delivery and the postpartum period ${ }^{15}$.

In order to address maternal complications, knowledge, attitudes and practices of maternal needs to be evaluated to provide correct and proper intervention. In the current study, pregnant women are knowledgeable over the importance and implications of prenatal check- up, which are in congruence with the previous study by Greg (1995), where it is stress that prenatal care has long been endorsed as a means to identify mothers at risk of delivering a preterm or growth-retarded infant and to provide an array of available medical, nutritional, and educational interventions intended to reduce the determinants and incidence of low birth weight and other adverse pregnancy conditions and outcomes ${ }^{16}$. However, there are still pregnant who doesn't believe that being diabetic may cause them to have a big baby and according to Akadiri (2011), obesity and diabetes in pregnancy have independent and additive effects on obstetric complications, and both require proper management ${ }^{17}$.And thus regular follow-up, controlled diet and life style are essential to control the hyperglycemia in diabetic pregnancies. And in addition it can be noted that, only few believed that they only have to see a doctor for prenatal care if they are sick and according to Warren (2010) the care seeking behavior of a person is related to recognition of the cause and severity of the complication ${ }^{18}$. However there are many factors to consider why availing of maternal health services becomes a hindrance this is also supported with the study conducted in Ethopia some of the women who reported complications did not seek services due to reasons, like inability to judge the graveness of the condition, distance/transport problems, lack of money/cost considerations and use of traditional options at home ${ }^{19}$.

As to attitude, findings indicated that pregnant women agreed having an interpretation of positive attitude concerning pregnancy especially with regards to prenatal check-up and according to Sherbini et al. (1993) where in $80 \%$ of pregnant women also observed that prenatal check-up is important to maternal and fetal well-being ${ }^{20}$. Taking nutritional supplement during pregnancy is also a favourable attitude wherein it helps the growth and development of fetus and that is intended to cover gaps in maternal nutrition and to decrease the risk of adverse outcomes such as neural tube defects ${ }^{21}$. Moreover, findings indicated that pregnant women strongly agreed having high positive attitude with regards to avoidance of maternal smokingand it is believed that one of the effects of maternal smoking during pregnancy and environmental tobacco smoke are asthma and wheezing in children ${ }^{22}$. In one study conducted it revealed that there was a strong relationship with significant relationship between smoking and all observed birth outcomes, there were significant reductions in birth weight (by $205 \mathrm{~g}$ ), birth length (by $1.28 \mathrm{~cm}$ ), head circumference (by $0.38 \mathrm{~cm}$ ) and chest circumference (by $0.66 \mathrm{~cm}$ ) found to be associated with an average daily smoking of 10 or more cigarettes after adjustment was made for potential confounders ${ }^{23}$. However, result of this investigation disagrees with the study conducted by Passey et al., (2012) which reflected almost 79\% of pregnant women reported smoking during pregnancy and the study of Muhamad et al. (2011) which reported 25\% of pregnant women believe that alcohol drinking during pregnancy doesn't have harmful effects to the fetus. This further implied that alcohol drinking/smoking mothers have low birth weight infants because of the resultant vasoconstriction of uterine vessels as an effect of alcohol content/nicotine that hereby limits blood supply to the fetus (Pillitteri, 2003).

Aside from the attitude and knowledge, it also believed that good maternal practices, utilization of maternal services and behavioral factors ${ }^{24}$ help reduce the incidence of perinatal morbidity and mortality and to help women address complications. In this study it can be seen that all of the respondentspractice not to smoke during pregnancy. However, majority of them do not drink maternal milk wherein it is emphasized in the study by Borazjani, et.al, thatthe rate of growth of fetus was highly influenced by maternal milk and protein intake by the mother ${ }^{25}$. Findings also indicated that significant numbers of mothers also do not check blood sugar level that does not comply with the guidelines on prenatal care. With practice fetuses are put in higher risk for complications ${ }^{26}$.

Factors determination and effects association are very important. The implications of the study findings highlight the need for prospective mothers to prepare a safe pregnancy plan as a strategy for improving birth preparedness. Safe pregnancy plans should start with ensuring that prospective mothers have adequate knowledge and information about safe motherhood practices while taking into consideration their obstetric history ${ }^{27}$. It has been 
identified in the study that there were no relationship between knowledge and the confounding variables. This finding is in complete disagreement with that of Dr.Kathia Van Egmond (2002) study, wherein the educational attainment has intent with regards to knowledge on pregnancy, which the longer the pregnant woman went to school, the better her knowledge parameters in general, especially when it comes to maternal and child care ${ }^{28}$. Knowledge of key danger signs isalso an essential for motivating women to seek skilled attendance at birth and also to seek referral in case of complications.

As to attitude it is further indicated that no matter what the age, marital status, educational attainment, occupation and family's monthly income of the respondent, it won't affect her attitude to pregnancy. This is contrast in the study by Chang that Mothers and children benefited when maternal attitudes were consistent with the mothers' actual employment status ${ }^{29}$. Among consistently employed mothers, those with positive attitudes about employment had better psychological well-being and could give a better nutrition but when mothers were unemployed, it is believed that maternal employment would have positive consequences for their children's development, and likely to show a low level of psychological well-being and poor quality of mother-child relation.

As to practices, no correlation were seen in the study wherein it contradicts in the result conducted by Barbara L. Cannella (2005) that the higher the income of the family perceived, the more pregnant women engaged in good health practices ${ }^{30}$. According to UNAIDS (2005) report, education plays an important role in predicting how well an individual is able to incorporate current lifestyle messages into their sexual behavior ${ }^{31}$. The level of education of the sample may have accounted for the increased self-care practices during pregnancy, mean score 24.32 out of 42 with a corresponding improved birth outcomes, mean score 8.99 out of $15^{32}$.

\section{Conclusions:-}

It could be inferred from this study that there are no relation of knowledge, attitude and practices as to maternal variable (age, marital status, educational attainment, occupation and monthly income). However, researchers would like to recommend that pregnant women should indulge in activities; campaign and other program and there should be a foregoing analysis that will help improve their knowledge, attitudes and practices and will enable them to provide appropriate health teachings on pregnancy related concepts.

\section{Acknowledgement:-}

Investigator would like to thank all the participants for their time and effort in responding to the questionnaires.

\section{Conflict of Interest:-}

The authordeclares that they have no competing interests.

\section{References:-}

1 Division of Reproductive Health, National Center for Chronic Disease Prevention and Health Promotion

2 Gurmesa Tura Debelew, MesganawFantahunAfework, \&AlemayehuWorkuYalew' Factors affecting birth preparedness and complication readiness in Jimma Zone, Southwest Ethiopia: a multilevel analysis, The Pan African Medical Journal - ISSN 1937-8688, 2014

$3 \quad$ Pillitteri, 2010

4 World Bank. Safe Motherhood- a review. The Safe Motherhood Initiatives, 1987 - 2005

World Bank Report. New York: Family Care International, 2007

5 WHO, UNICEF, UNFPA, World Bank and UN Population Division Maternal Mortality

$6 \quad$ The Uganda Quality of Care Survey of Family Planning and Antenatal Care Servic es

$7 \quad$ World Health Organization Maternal mortality: Fact sheet No. 348 (WHO, updated May 2014) 
$8 \quad$ Megan E Passey, Catherine A D'Este ,Robert W Sanson-Fisher, Knowledge, attitudes and other factors associated with assessment of tobacco smoking among pregnant Aboriginal women by health care providers: a cross-sectional survey, BMC Public HealthBMC series - open, inclusive and trusted201212:165, (C) Passey et al; licensee BioMed Central Ltd. 2012, Published: 7 March 2012

9 Stevenson, Ian, A New Look at Maternal Impressions: An Analysis of 50 Published Cases and Reports of two Recent examples, Journal of Scientific Exploration. Vol. 6. No. 4. DV. 353-373. 1992 0892-33 10192, Department of Behavioral Medicine and Psychiatry, University of Virginia School of Medicine, Charlottesville, Virginia 22908

10 Percy Gamble Kammerer, The Unmarried Mother: A Study of Five Hundred CasesCriminal Science Monographs, No. 3, (Jan., 1918), pp. 1-337

11 Ojong, Idang N, Uga Adaora, L.,\& Chiotu, Catherine N., Knowledge and Attitude of Pregnant Women towards Focused Ante Natal Care Services in University of Calabar Teaching Hospital, Calabar, Cross River State, Nigeria, International Journal Of Midwife And Health Related Cases Vol.1, No.1, Pp.14-23, March 2015

12 Ribeiro, C. P., Milanez, H., Knowledge, attitude and practice of women in Campinas, Sao Paulo, Brazil with respect to physical exercise in pregnancy: a descriptive study, Reproductive Health,http://www.reproductive-health-journal.com DOI: 10.1186/1742-4755-8-31

13 Center for Disease Control and Prevention, Control Division of Reproductive Health

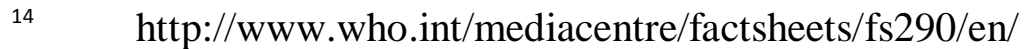

15 Gurmesa Tura Debelew, ', MesganawFantahunAfework, AlemayehuWorkuYalew' Factors affecting birth preparedness and complication readiness in Jimma Zone, Southwest Ethiopia: a multilevel analysis, The Pan African Medical Journal - ISSN 1937-8688, 2014

16 Greg R. A. and KorenbrotC. C., The Role of Prenatal Care in Preventing Low Birth Weight, , The Future of Children, Vol. 5, No. 1, Low Birth Weight (Spring, 1995), pp. 103-120

17 Yessoufou, A.and Moutairou, K., Maternal Diabetes in Pregnancy: Early and Long-Term Outcomes on the Offspring and the Concept of "Metabolic Memory", Experimental Diabetes Research Volume 2011 (2011), Article ID 218598, 12 pages,

18 Charlotte Warren, Care seeking for maternal health: challenges remain for poor women, Ethiop. J. Health Dev. 2010;24 Special Issue 1:100-104

19 Killewo J, Anwar I, Bashir I, Yunus M, Chakraborty J (2006) Perceived delay in healthcare-seeking for episodes of serious illness and its implications for safe motherhood interventions in rural Bangladesh. Journal of health, population, and nutrition 24: 403-412.)

$20 \quad$ Sherbini, A., Torky, M.et al., (1993). "Assessment of Knowledge, Attitudes and Practices of Expectant Mothers in Relation to Antenatal Care in Assiut Governorate". High Institute of Public Health, Alexandria University, Egypt Public Health, Assoc., 1993.

21 Reem H, Olshan, A. F, Herring, Am. H., Savitz, D. A., Siega-Riz, A. M., andHartmann, K. E., Self-reported Vitamin Supplementation in Early Pregnancy and Risk of Miscarriage, Correspondence to ReemHasan, Department of Epidemiology, School of Public Health, University of North Carolina-Chapel Hill, Chapel Hill, NC 27599-7435 
22 Gilliland F. D., Li Y.F., Peters J. M., Effects of maternal smoking during pregnancy and environmental tobacco smoke on asthma and wheezing in children., American Journal Respiratory Critical Care Med. 2001 Feb;163(2):429-36.

23 Vlajinac H, Petrović R, Marinković J, Kocev N, Sipetić S., The effect of cigarette smoking during pregnancy on fetal growth., National Center for Biotechnology Information, 1997 Sep-Oct;125(9-10):267-71.)

24 US Department of Health and Human Services: Healthy People 2010. Maternal, Infant, and Child Health. Chapter 16. Vol. II, 2nd ed. 2000, [http://www.healthypeople.gov/document/ html/volume2/16mich.htm

25 Fatemeh Borazjani, KambizAhmadiAngali and Shanuak S. Kulkarni,Milk and Protein Intake by Pregnant Women Affects Growth of Fetus, Journal on Health Population Nutrition. 2013 Dec; 31(4): 435-445.PMCID: PMC3905637

26 Jensen DM, Korsholm L, Ovesen P, et al, Peri-conceptional A1C and risk of serious adverse pregnancy outcome in 933 women with type 1 diabetes. Diabetes Care 2009; 32:10461048

27 EkechiO.,Susan A.,Adekunle A., Mustapha T., Ibrahim Y., and Benson O., Reproductive Health. 2013; 10: 57.Published online 2013 Oct 26. doi: 10.1186/1742-4755-1057PMCID: PMC4176136Knowledge of safe motherhood among women in rural communities in northern Nigeria: implications for maternal mortality reduction

28 Egmond (2002). "Knowledge, Attitude and Practices Survey RegardingReproductive Health". International Centre for Reproductive Health, University of Ghent, Belgium, 2002.

29 Chang Y. E., The Relation Between Mothers' Attitudes Toward Maternal Employment and Social Competence of 36-Month-Olds: The Roles of Maternal Psychological Well-Being and Sensitivity, Journal of Child and Family Studies, 10.1007/s10826-012-9660-7, October 2013, Volume 22,Issue 7, pp 987-999

30 Yarcheski A., Mahon, N. E., Thomas J. Yarcheski, Michele M. Hanks, Barbara L. Cannella, A meta-analytic study of predictors of maternal-fetal attachmen, International Journal of Nursing Studies 46 (2009) 708-715

31 Eaton, Jeffrey W.; Rehle, T. M., Jooste, S., Nkambule, R., Kim, A. Mahy, M., Hallett, T. B., Recent HIV prevalence trends among pregnant women and all women in sub-Saharan Africa: implications for HIV estimates, Official Journal of the International AIDS Society, November 2014 - Volume 28 -Supplement 4 pp: S411-S542

32 Gomora, A., Doreen Mukona, D., Zvinavashe, M.,\& Dhaka, A. The relationship between prenatal self care and adverse birth outcomes in young women aged 16 to 24 years, IOSR Journal of Nursing and Health Science (IOSR-JNHS) e-ISSN: 2320-1959.p- ISSN: 2320-1940 Volume 4, Issue 1 Ver. II (Jan.-Feb. 2015), PP 72-80 www.iosrjournals.org DOI: 10.9790/195904127280 